\title{
International Order Maintenance Mechanisms in the Contemporary System of International Relations
}

\begin{abstract}
The article explores the main mechanisms of the maintenance of international order in a contemporary system of international relations. Within the system of international relations an order status is maintained by mechanisms of two types: organized and elemental. In this context, the mechanisms for maintaining order can be divided according to not only the degree of organization but also the content. From this perspective, the following mechanisms of international order were distinguished: institutional, regulatory-legal, economic, political-military, cultural, ideological and informational. International order is the sum of certain rules and principles established by all countries; those that they observe are built on the interaction of different factors.
\end{abstract}

Keywords: international order, modern system of international relations, rules and regulations, anarchy, mechanisms for maintaining order

The emergence of the category of international order in the theory of international relations causes the emergence of scholars who are engaged in theoretical aspects of international relations and issues related to the research of the concept of international order, its nature, types and mechanisms.

It is believed that the study of the problem of international order is one of the primary theoretical tasks, since contemporary world politics is characterized by the exacerbation of conflicts and contradictions as well as an increase of the random processes. However, the theoretical level of the problem of international order does not correspond to its relevance. This problem has taken a central place because it concentrates on the vision of interacting social communities in the global arena, which are integral components or elements of a single society.

The analysis of international political order paves the way for understanding the structure of stable relations between the elements of the system of international relationships that determine the nature of its functioning and development 
in certain time space. It should be noted that in the conceptual and categorical terms the problem of social and political order, and the order in international relationships, has not yet been investigated enough. Anyway, currently accumulated scientific-theoretical information lags far behind the needs of the time.

The subjects of international relations have been and continue to be interested in this activity being always beneficial for them and never destructive. That is why the international system almost always, although to a different extent, needed to streamline, regulate behavior, and regulate the actions of states in the environment according to the dominant views at a particular historical moment on the nature of its functioning. This need became especially urgent after the appearance of universal human values, international institutions, and transparency of borders and societies.

In modern scientific literature, especially American and British, the concept of international order is one of the key concepts. According to J. Ikenberry, professor at Georgetown University and one of the leading contemporary researchers of the problems of the world political development, "the central problem of international relations is the problem of order: how it is built, which mechanisms support it, and how it is destroyed and restored". This problem raises the question of what powers transform many autonomous individuals to the society and how the structure of the "force field" that ensures the functioning and development of the social system looks like.

At various stages of operation and development of the international system the ratio of means and methods of maintaining order was specific. During the evolution of the international system not only the means and methods of maintaining order change, but so do its dimensions. If during the early period of human development the ordering of international relations had a fragmented, separately-regional character, than with the expansion and consolidation of the world economic, political and cultural ties (especially beginning with the epoch of Discovery) by the end of $19^{\text {th }}$ - early $20^{\text {th }}$ century, order was established on a global scale. However, there are reasons to believe that order became truly global only as a result of globalization, which had become more intensive since the 1970s and led to final transformation of the international community into a whole system which differed by its interconnectivity and interdependence ${ }^{2}$.

1 J. Ikenberry, After Victory. Institutions, Strategic Restrain, and the Rebuilding of Order After Major Wars, Princeton 2000, p. 129.

2 D. Jacobson, Old Nations, New World: Conceptions of World Order, New York 1994, p. 180. 
The development of the world system was accompanied by a legal registration of the transforming manner of international treaties and agreements (Westphalian in 1648, Vienna in 1815, Versailles-Washington after First World War, the Yalta-Potsdam after the Second World War). Because of this, some authors identify certain types of historical order. Some speak of the Westphalian and modern system of international order that was made after the end of the "Cold War". A. Bogaturov adds to these types the Vienna (1815-1825), the Versailles (1918-1938), the Yalta-Potsdam (1945-1991) types of international order ${ }^{3}$.

Order parameters (stability, scale, fullness, and strength) depend heavily on the structure of the international system and on the relations between major states. However, most of the supporters of the "pole theory" are convinced that only a bipolar system is capable of providing a stable order in the world, although there are authors who stick to different perspectives.

International order is not homogeneous. In fact, many orders exist in the world at the same time as long as the international system is composed of a large number of subsystems. Each one differs from others in degrees of severity of indicated parameters.

In the international system the state of order is supported by mechanisms of two types: organized and spontaneous. Organized mechanisms involve the use of the complex of conscious deliberate acts performed by the system of management in order to regulate international relations. These mechanisms operate in all social systems created by a man as their distinguishing feature is commitment.

The order in the international system does not occur by itself but it is the result of efforts, organizing human actions that allow to build relations between peoples and nations, make them predictable and subordinate to certain rules and regulations. A. Grigoriev calls a social order that emerged as a result of conscious rational action a "necessarian model" of order. In this model, the international order is supported by some organizations, especially such global as the UN, IMF, International Court of Justice and others ${ }^{4}$. There are also institutions at the regional, sub-regional and other levels.

International organizations produce rules and regulations that regulate the relations of actors of world politics, monitor their compliance, and apply sanctions against offenders. However, the organized mechanisms of maintenance of international order are not always effective and have limited capacity. This is due to

3 K. Jaspers, The origin and goal of history, New York 2010, p. 29.

4 A.A. Grygoriev, Conceptual models of formation the social order and development trends, Social and humanitarian knowledge: Research School Edition, Moscow 2005, No. 2, p. 295. 
the specifics of the international system. Unlike other social systems, it has largely a decentralized nature. Therefore, some researchers call the system of international relations "anarchic"s.

Uncontrollability of international relations should not be exaggerated; however, highly centralized management of the international system, including its arrangement, indeed is impossible, at least in the short term. This can be explained by the following reasons:

- a large number of the world centers of power that act on behalf of sovereign states;

- divergence of interests of actors in international politics;

- lack of cultural and ideological commonality in the international system.

According to this, the centuries-old hope of forming a world government that was even supported by the founders of the school of political idealism (F. Vittoria, H. Grotius, I. Kant), is still overwhelming. The conclusion that the model of the world government is already represented by the US and its allies can also be considered unfounded.

It is difficult, however, to agree with those researchers who claim that in the whole world "there can never be the single (resource-compulsory) center of political power that would be able to set a stable and uniform orientation of develop-

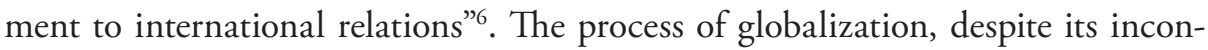
sistency, strengthens the interdependence of international actors and expands and deepens the cooperation between them, including the area of maintaining order.

Moreover, the institutional forms of this cooperation can have non-standard character, such as network management of international processes. The governments of sovereign states and international organisations may become its part including NGOs and TNCs. Also, it is likely that institutional mechanism for effective world order will include the union of the leading, most developed countries, being able to effectively coordinate the efforts to streamline international relations and to become the political center in this way.

In addition to purposeful activity of certain organizational structures, the order in the world is supported by natural mechanisms of self-organization. They are based on objective processes and phenomena (e.g. global issues) that establish and strengthen relations between states and non-state actors, making them interdependent and making them follow (unconsciously or consciously) certain rules

5 H.N. Bull, The Anarchical Society: A Study of Order in World Politics, New York 2012, p. 46.

6 S.V. Kortunov, The Collapse of the Westphalian System of International Relations and the Emergence of a New World Order, Saint Petersburg: GU-VSHE, 2007, No. 2, p. 88. 
in relations between one another. According to J. Rosenau, the "invisible hand" that organizes and directs the actions of disparate actors in world politics is valid in international relations?

In clashes and intertwining of their interests and efforts by "trials and errors" the models and designs of political behavior, rules, customs and regulations are created. Attempts to change the rules in their favor produce a compensatory process and the resistance of other actors that leads to the restoration of balance and order in the international system.

The need of states to spontaneously maintain order is conditioned, on the one hand, through the shortage of effective centralized mechanisms of normalization in the world, and on the other hand - the presence of some common interests among the actors of international politics: security, maintenance of well-being, addressing environmental issues, etc. As it has already been noted, if the international "rules of the game" will not be followed at all, it is impossible to guarantee the implementation of the abovementioned interests and consequently the survival of humanity.

As a result, there appears a kind of self-organizing system of "international elements". Particular attention to natural mechanisms of international system regulation is paid by the representatives of synergy. Originating in the 1970s, this research area became popular among a large part of international scientists. From the perspective of synergy, the ways of development cannot be imposed on complex, open and nonlinear systems, such as the international system, but there is a possibility of their self-organization and spontaneous development ${ }^{8}$.

The organization appears without controlled commands through local interactions between the elements that "trigger" an internal mechanism of self-organization. The mechanism of self-support of the order in such systems is as follows. Fluctuations, i.e. random deviations from the condition of balance that are strong and large-scale, cause competitive interactions between them. The system is "swinging" and instability increases until it reaches the point of bifurcation (branching) $)^{9}$.

This point is characterized by fundamental unpredictability: it is unknown if the development of the system will become chaotic or if there will appear a new, more orderly dissipative structure. Thus, the scheme of the mechanism of self-organization of nonlinear systems can be expressed as: order - chaos - order.

J. Rosenau, Turbulence in World Politics: A Theory of Change and Continuity, Princeton 1990, p. 104.

8 V.O. Altuhov, Change of Orders in a World Social Development, Moscow 1995, No. 4, p. 12.

9 Ibidem, p. 15. 
It should be stressed that there is much reason to synergy (for example, justification of mutual transitions of order and chaos, the study of mechanisms of self-organization in open systems, etc.). However, its conclusions are not absolute. If they are considered to be fully justified in natural sciences, their use in the analysis of social processes (social synergy) needs serious scientific study. At least, borrowing concepts and methods from synergy requires their substantial modification.

This fully applies to the problem of self-organization. Admiration of social synergy led some authors to exaggerate the role of natural factors of international order: "All systems of the international relations that existed in a particular period of history belong to a class of systems with natural regulatory mechanism"10. Y.P. Trophimov also claims that in the international system the "principles of self-organization prevail over the principals of organization, this is understood as the activity of organizing, structuring and management of systems"11.

In fact, international order is maintained by both organized and natural mechanisms. However, their correlation on various stages of international systems' evolution, the same as the ratio of order and chaos, are different. Organized mechanisms, as a rule, tend to dominate in stable periods of history, and natural - in transient, unstable periods.

The mechanisms for maintaining order can by typolized not only by the degree of organization, but also by the content. From this perspective, we can distinguish the following means of international order:

1. Institutional. Their role in the ordering of international relations we have noted above. It should not be exaggerated, if we take into consideration a weak centralization of the international system, the same as detracted, especially that during the last decade there has been noticed the growth of the influence of various international organizations. P. Kennedy in this regard emphasizes: "The international institutions are capable to mobilize the sufficient political resources for supplying the supranational enforcement, overcoming at the same time the restrictions imposed by anarchy"12.

L. Miller also disagrees with the idea of complete anarchy of international organization structures, their inability to organize international activity. However, he notes that their effectiveness depends on specific situations. Indeed, in some cases, international organizations have shown their effectiveness in the application of sanctions against countries that violate

10 Y.P. Trophymov, The World Community as a Global System, Barnaul 2006, p. 32.

11 Ibidem, p. 33.

12 P. Kennedy, The Rise and Fall of the Great Powers: Economic Change and Military Conflict from 1500 to 2000, New York 1998, p. 87. 
international law (for example, against the racist regime of South Rhodesia and South Africa) ${ }^{13}$.

2. Regulatory-legal. International legal order is prepared as international law. This is a set of contractual and customary law principles and rules that represent a complicated legal complex, the subject matter of which are interstate and other relationships. Legal measures to maintain order provide guidelines that constrain the arbitrariness of international actors. International bodies (UN Security Council, the International Court, International Tribunal of the Law of the Sea, etc.) monitor the observance of international law. However, the rules international law apply only if the sovereign states agree with them and are willing to obey them. This fact significantly reduces the effectiveness of law enforcement in the world and leads to the fact that only a small number of international law regulations have universal application.

3. Economical. The value of economic factors in international relations in general and in the area of maintaining order in particular is growing today. Strengthening of economic ties, creating international regimes which regulate trade rules, and creating financial and transport connections, promote the ordering of international relationships and create interest in following the rules and obligations by the actors of the international system. Thus, economic integration occurs not only at national but also at the corporate level. Formation of a single type of business practices within the global economy brings economic mechanisms of regulation of international system to the forefront among other tools of building order ${ }^{14}$.

4. Political-Military. Armed force as a means of maintaining or restoring international order is used both by separate states and by their coalitions. However, maintaining peace and stability in certain regions by military units can be imposed according to the mandate of global, regional or international organizations (such as peacekeeping missions in Somalia, Burundi, East Timor, southern Lebanon in the 1990s - 2000s) or without it ( NATO action in Kosovo in 1999, Libya in 2011). In the last decades humanitarian operations to maintain order have been carried more and more often. Currently, only the UN peacekeeping forces ("blue helmets") perform their missions in 16 countries. However, humanitarian operations that are carried out against the will of sovereign states can produce the

13 L.H. Miller, Global Order: Values and Power in International Politics, Westview 1985, p. 59.

14 A. Libmann, A Corporate Model of Regional Economic Integration, Moscow 2007, No. 3, p. 17. 
opposite effect, as they can be a source of disorder and instability in the international system (e.g. occupation of Iraq by the coalition forces) ${ }^{15}$.

5. Cultural and ideological. The achievement of international consensus among the states on fundamental values certainly would contribute to following some certain rules and regulations in relations among the subjects of international policy. Representatives of various ideological political movements have their own idea of the values that can provide international order. For example, supporters of the Soviet ideology - Marxism-Leninism claimed that the order of the world was only possible after a global victory of communism ${ }^{16}$. Liberal-democratic forces believe that the international order should be based on liberal values. Thus, they rightly refer to the practice of relationships of democratic countries, in which no serious armed conflicts took place ("theory of democratic peace").

The proponents of universalism believe that values which are as the basis of international order should have a cross-cultural and universal character. A. Ettsioni defends the need for regulatory synthesis of Western and Eastern values that allows to combine respect for the human rights with the commitment to common wealth. Unfortunately, in a world divided ideologically and culturally, reaching a real consensus is still very far. Therefore, the valuable mechanisms of ensuring international order often do not show high efficiency.

6. Informational. It is obvious that in the context of globalization maintaining order in the world is impossible without a constant exchange of information between the elements of the international system. Today, the global information network is becoming an effective means of "cementing" international relations and organizing world political space. Density, speed and availability of modern information flows make the communication of individuals of international policies much easier and allow to quickly obtain information about the situation in different regions and the actions of other actors, to explain own position on certain issues, and to coordinate foreign policy activities ${ }^{17}$. This enhances the ability of international organizations and individual states to regulate global processes by making them more ordered.

15 A. Etzyoni, From Empire to Community: A New Approach of International Relations, Moscow 2004 , p. 29.

16 Ibidem, p. 34.

17 N. Chomsky, Hegemony or Survival. America’s Quest for Global Dominance, New York 2003, p. 110. 
The maintenance of order - is not the order itself. These are institutional, economic, cultural, ideological, and informational tools of streamlining international relationships, ensuring their organization and predictability.

In terms of methods of maintaining international order we can distinguish:

1. Order of fear (which is supported by force, by means of various kinds of sanctions applied both by international organizations and by some of the most influential actors of the world politics in relation to offenders);

2. Order of interest (which is based on the interest of the parties in support of an order and benefits that are derived from a stable, predictable international cooperation);

3. Order of consent (which is due to voluntary compliance to international relations rules and regulations by the subjects, based on specific principles and ideals $)^{18}$.

It is possible to make the assumption that the current order of fear particularly supported by military force is gradually replaced by the order of interest, although this process is complex and controversial.

There are two possible answers to the question of functioning of the international political agenda in the near future:

1. The order will strengthen and improve;

2. Chaotic processes will grow.

Considering the complex dialectic of order and chaos in the international system and their mutual transitions into each other, to make an accurate prediction of the world processes development is difficult.

But, nevertheless, the position of strengthening the international order is considered more reasonable. Firstly, the system of international relations has a large margin of safety, strong potential of support and recovery of order and immanent system. Secondly, under the influence of globalization, the world becomes more interdependent and the growing number of internal connections strengthens the ordering system. Thirdly, greater part of humanity more often recognizes the need for submission of international relations to some rules and regulations on tha basis of purely practical reasons: considering the scale of global problems, without them we cannot survive and ensure safety. Therefore, the international order will become more mature, acquiring systemic stability, although this process will be connected with a struggle between opposing tendencies.

18 A.M. Slaughter, A New World Order, Princeton 2004, p. 172. 